\title{
OPERATION OF A POWER UNIT AS A PEAK UNIT AND ITS IMPACT ON THE ECONOMY AND RELIABILITY OF THE POWER SYSTEM
}

\begin{abstract}
Wind power plants are at the forefront of the development of renewable energy sources (RES) but their operation depends on changing weather conditions. Favouring energy obtained from renewable sources forces the operation of conventional energy as a regulator balancing the system's demand. Coal-fired power units were designed for continuous operation and their efficiency decreases if they are used as peak units. The increased number of start-ups and frequent fluctuations in the generated power lead in the long run to the accumulation of consumption processes such as thermal fatigue and cracking. Another noticeable effect is also the decrease in reliability indicators and increased operating costs associated with expensive start-ups. The paper presents an estimation of operating costs related to more frequent start-ups of a power unit. The impact of the deterioration of reliability indicators on the production capacity of a single power plant as well as the reliability of the entire system was also analysed.
\end{abstract}

Keywords: power unit, wind power plants, peak unit, reliability of the power system

\section{PRACA BLOKU ENERGETYCZNEGO W CHARAKTERZE JEDNOSTKI SZCZYTOWEJ I JEJ WPEYW NA EKONOMIE I NIEZAWODNOŚĆ SYSTEMU ELEKTROENERGETYCZNEGO}

\begin{abstract}
Siłownie wiatrowe stoją na czele rozwoju odnawialnych źródeł energii (OZE), lecz ich praca zależy od zmiennych warunków pogodowych. Faworyzowanie energii uzyskanej z odnawialnych źródeł wymusza pracę konwencjonalnej energetyki jako regulatora bilansującego zapotrzebowanie systemu. Bloki węglowe projektowane byly do pracy ciagłej $i$ ich sprawność spada, jeżeli użytkowane sa jako jednostki szczytowe. Zwiększona liczba rozruchów $i$ częste fluktuacje mocy generowanej prowadza $w$ dtuższej perspektywie do kumulacji procesów zużycia takich jak zmęczenie cieplne i pękanie. Innym zauważalnym efektem jest równiė̇ spadek wskaźników niezawodności $i$ zwiększone koszty eksploatacji zwiazane $z$ drogimi rozruchami. W artykule przedstawiono oszacowanie kosztów eksploatacji związanych z częstszymi rozruchami bloku energetycznego. Analizowano również wpływ pogorszenia się wskaźników niezawodności na możliwości produkcyjne pojedynczej elektrowni jak i na niezawodność całego systemu.
\end{abstract}

Stowa kluczowe: blok energetyczny, siłownie wiatrowe, jednostka szczytowa, niezawodność systemu

\section{INTRODUCTION}

For several years in Europe, there has been a dynamic change in the structure of energy sources supplying domestic systems. The driving force behind these changes is, among others: efficiency of fuel energy use, costs of electricity generation, safety and reliability of power plant operation, depleting fuel resources and, what has been the most important recently - ecology. The ecological aspect has its supporters and opponents. EU legislation has forced pro-ecological changes in the structure of energy sources. Among renewable sources, the leader is wind energy, the operation of which depends on changing weather conditions. Giving priority to energy from RES forces the operation of some conventional units as a safeguard for wind power plants and causes difficulties in balancing the system's demand.
In August 2015, for the first time in 30 years, the "20th power rationing level" was implemented, which in short means limitations in energy consumption for industrial customers. The steps taken were to prevent the system blackout. The main reason for this state of affairs was the long-term heat, which limited the possibility of cooling the steam-water circulation of power plants. The low water level in the reservoirs limited the production capacity of water power, and the high-pressure windless weather immobilised almost $4.5 \mathrm{GW}$ of power installed in wind power plants. The summer period is also a natural time to carry out scheduled repairs of power units, which has further intensified the power deficit. All these reasons coincided with time, which resulted in the inability to cover the demand for electricity.

Figure 1 shows the course of changes in the maximum power demand in the national system in the pe- 
riod 2002-2018. The data were estimated based on the daily courses of demand made available at the Polskie Sieci Elektroenergetyczne website [1]. Interesting facts can be noticed when analysing these courses. The day of maximum demand falls in the winter period, most often in the last 3 weeks of January or in the first 3 weeks of December; it is usually the day in the middle of the week between 4:30 and 5:30 p.m.

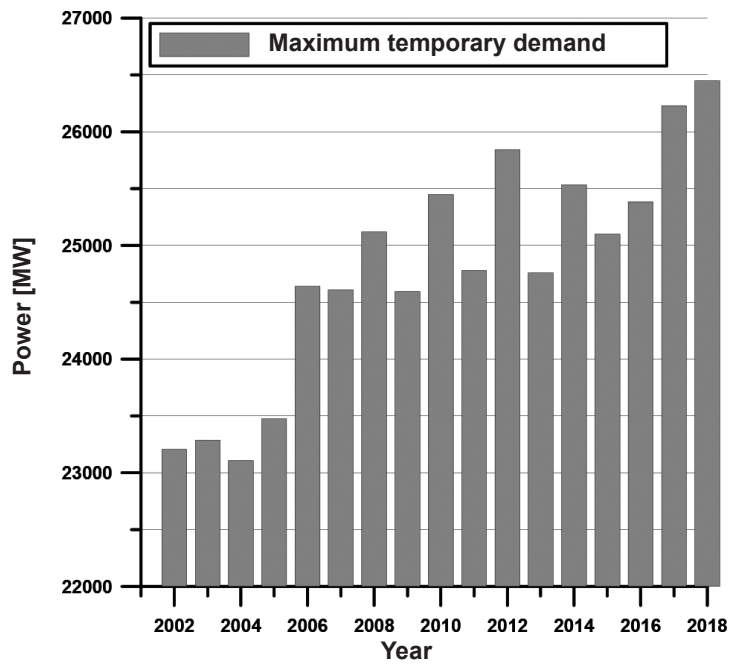

Fig. 1. Peak power demand in 2002-2018

Rys. 1. Szczytowe zapotrzebowanie mocy w latach 2002-2018

The maximum demand for energy in the years 2002-2005 was at the level of 23-23.5 GW. During this period, the capacity installed only in coal-fired utility power plants was greater than the maximum demand. In the next period, the demand has risen sharply and is currently at the level of about $26.5 \mathrm{GW}$, which is $3 \mathrm{GW}$ more than the power installed in coal-fired utility power plants indexed in the Energy Market Agency (ARE) catalogues.

In the last 10 years, 4 supercritical units with a total capacity of $2.8 \mathrm{GW}$ were commissioned, replacing the old units. In 2018-2021, the commissioning of further units with the total capacity of about $3.1 \mathrm{GW}$ is planned, however this will not improve the system's situation, because in this period, about 30 used 120 and $200 \mathrm{MW}$ units with comparable total power will be decommissioned. Therefore, in order to maintain the current growth rate of demand, it is necessary to plan further large energy investments. Otherwise, the situation from August 2015 will be repeated. For a full picture of the situation, Figure 2 shows the increase in capacity installed in wind power plants. A stagnation of new investments caused by a change in regulations can be seen currently.

Over half of utility power units in Poland have already exceeded the designed operating time $(200,000 \mathrm{~h})$. Used units are characterised by continuous deterioration of reliability indicators. The course of the most important indicators, i.e. forced outage rate FOR and availability factor AF, are presented in Figures 3 and 4 [2].

The article analyses the financial and reliability effects of the operation of several power plants as a safeguard for wind power plants. This type of operation is associated with an increased number of start-ups and frequent power fluctuations. The analysis was carried out for a single power plant, as well as globally for the entire system.

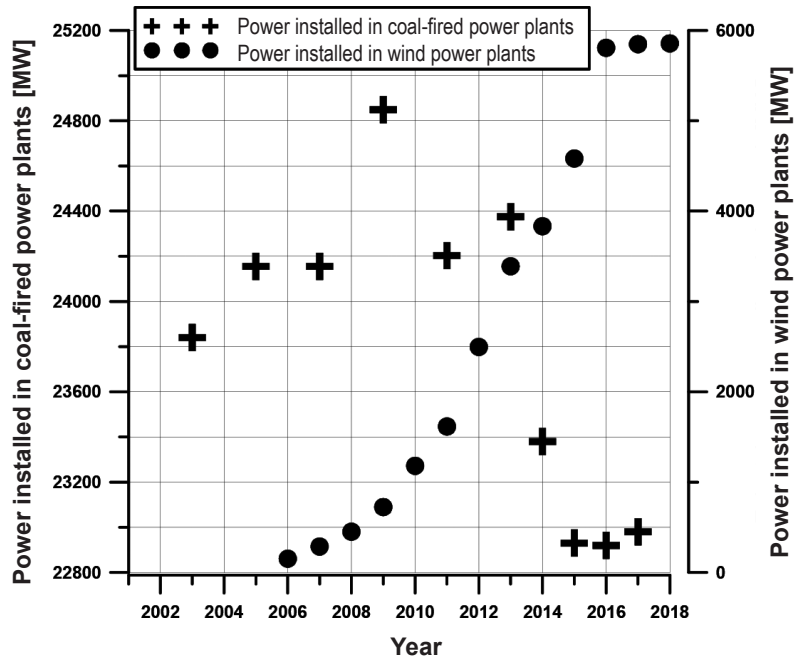

Fig. 2. Power installed in coal-fired power plants (ARE) and wind power plants in 2002-2018

Rys. 2. Moc zainstalowana w elektrowniach weglowych (ARE) oraz w siłowniach wiatrowych w latach 2002-2018

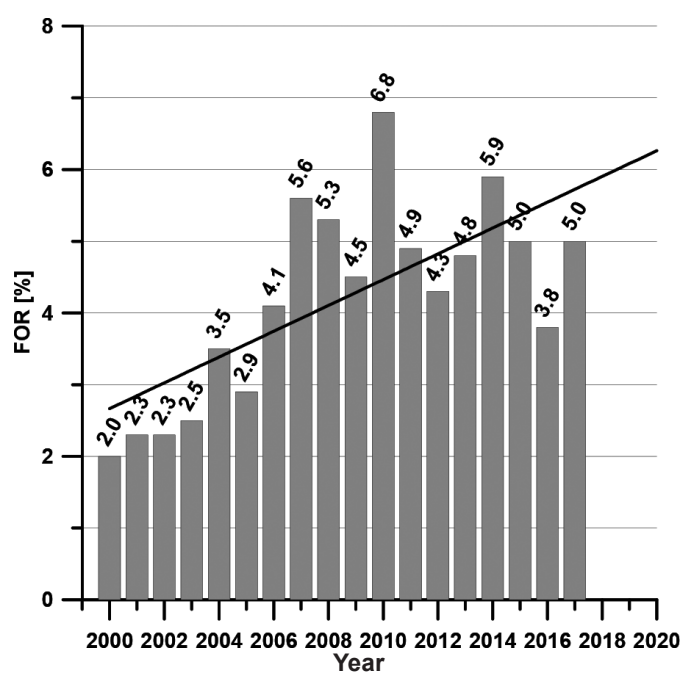

Fig. 3. Forced outage rate FOR

Rys. 3. Wskaźnik awaryjności FOR

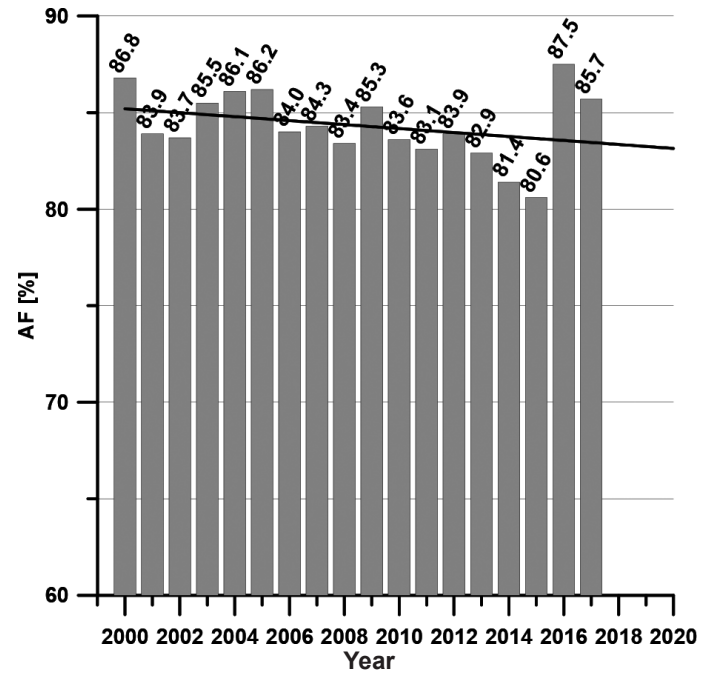

Fig. 4. Availability factor AF

Rys. 4. Wskaźnik dyspozycyjności AF 


\section{EFFECTS OF INCREASED CYCLICALITY OF OPERATION FOR A SAMPLE POWER PLANT}

The use of a coal-fired power plant as a peak unit or as a reserve energy source securing wind power plants carries increased operating costs, and in the future, also renovation and investment costs [3, 4]. Increased renovation and investment costs are associated with the irreversible accumulation of wear processes, mainly low-cycle fatigue and cracking processes. Each startup or modification of the unit's power causes the stress amplitude to arise, which intensifies the wear processes, therefore the durability of the used units will be shorter. Increased operating costs result from more frequent start-ups. Start-up is an ineffective phase of the power plant operation; it requires considerable financial outlay, and at the same time it does not generate profits. The main components of start-up costs are: - the cost of energy necessary to supply own needs (drives of pumps, fans, mills, etc.)

- the cost of expensive light-up fuel and primary fuel used up to the moment of synchronisation with the system.

Start-up costs for a medium power coal-fired unit from warm state have been estimated in the world $[5,6]$ and domestic [7] literature at a similar level of around $60 \$ / \mathrm{MW}$ of unit power. The increase in operating costs related to the increase in the number of startups for a sample power plant composed of $8200 \mathrm{MW}$ units was analysed. The data necessary to carry out multivariate calculations were borrowed from a real utility power plant. The average number of start-ups of a single unit was determined based on the analysis of the history of operation of this power plant in the years 2000-2015. The unit's average forced outage rate FOR was also calculated. Input data are shown in Table 1.

Table 1. Input data

Tabela 1. Dane wejściowe

\begin{tabular}{|l|c|}
\hline Average annual number of start-ups & $26 /$ unit \\
\hline Unit's average forced outage rate FOR & $2.44 \%$ \\
\hline $8 \times 200$ MW power plant's total power & $1600 \mathrm{MW}$ \\
\hline Average start-up cost & $60 \$ / \mathrm{MW}$ \\
\hline Average start-up time & $4 \mathrm{~h}$ \\
\hline Energy market value & $53 \$ / \mathrm{MWh}$ \\
\hline
\end{tabular}

The operation of a power plant as a safeguard for wind power plants is associated with an increased number of start-ups, which is why their increase by 50, 100 and 200\% was analysed. During start-ups, the unit does not generate power and therefore it does not generate profit. The share of net profit in the market value of energy produced is difficult to estimate and is a trade secret. Therefore, the market value of non-produced energy due to the start-up was determined assuming that $1 \mathrm{MWh}$ costs $\$ 53$. The average start-up time was also assumed at the level of $4 \mathrm{~h}$. The results of the calculation are shown in Figure 5.

As already mentioned, the increase in the number of start-ups has an impact on the reliability of the power unit. Figure 6 shows the annual unit forced outage rate FOR as a function of the number of start-ups for individual units of the discussed power plant in the period

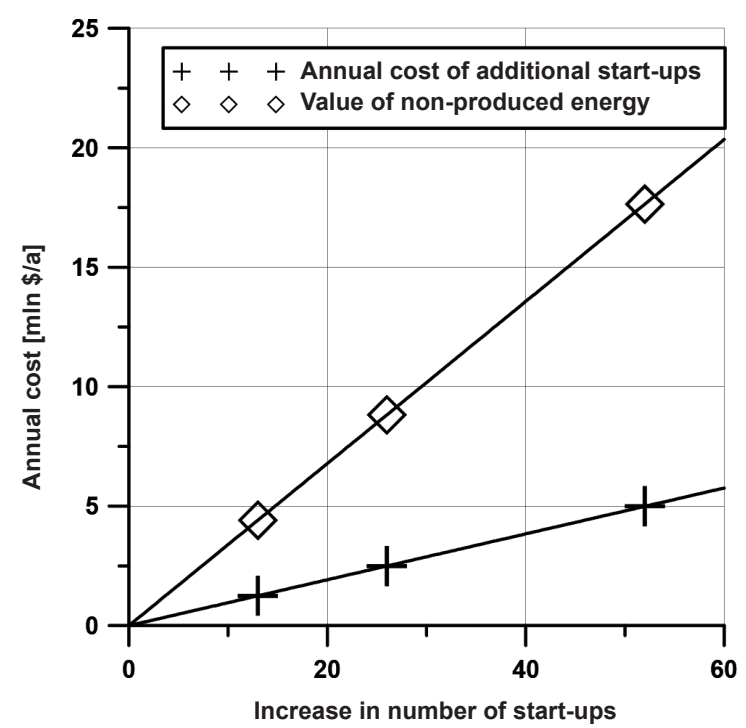

Fig. 5. Increase in costs associated with additional startups and the market value of non-produced electricity

Rys. 5. Wzrost kosztów związanych z dodatkowymi rozruchami oraz wartość rynkowa niewyprodukowanej energii elektrycznej

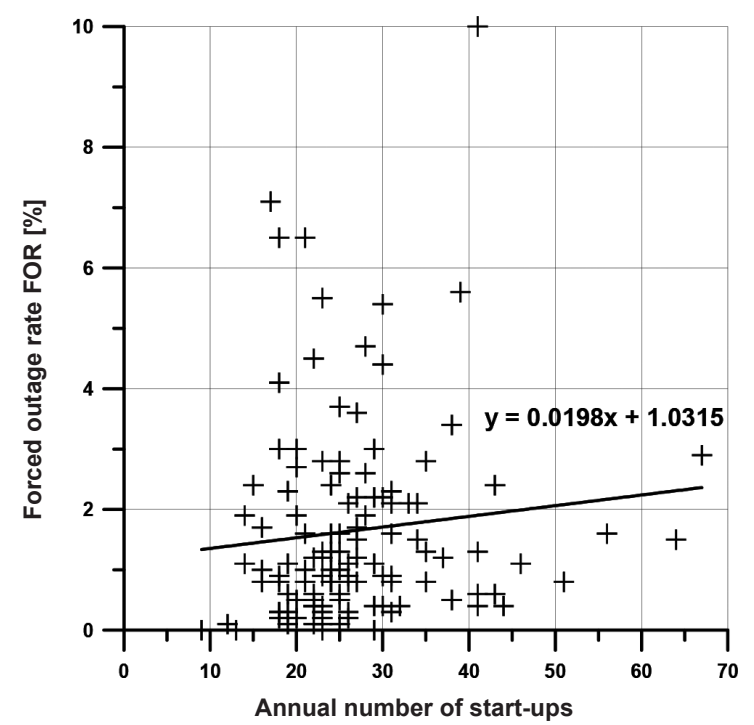

Fig. 6. Forced outage rate as a function of the number of start-ups

Rys. 6. Wskaźnik awaryjności w funkcji liczby rozruchów

2000-2015. The increase in the number of start-ups by $X$ start-ups per unit per year will cause an increase in the unit's forced outage rate FOR by $0.0198 X$ percentage points (Fig. 7).

In order to estimate the impact of the increase in the forced outage rate FOR on the operation of the entire power plant, the probability of operation of this power plant at various power levels was calculated. The likelihood of a simultaneous failure of " $k$ " units from among " $n$ " units making up a power plant can be estimated based on dependence (1).

$$
P_{k}=\frac{n !}{k !(n-k) !} q^{k} p^{n-k}
$$

where:

$q=$ FOR (initial value $2.44 \%=0.0244$ )

$p=1-q$ 


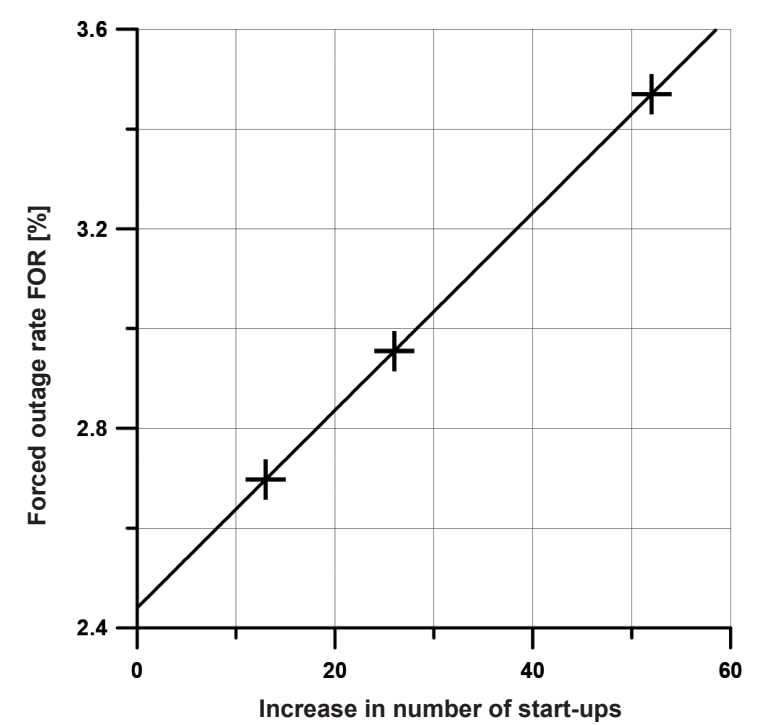

Fig. 7. Increase in forced outage rate FOR due to the increase in the number of start-ups

Rys. 7. Wzrost wartości wskaźnika awaryjności FOR wskutek wzrostu liczby rozruchów

As in previous considerations, an analysis was carried out for the increase in the number of start-ups by 50, 100 and $200 \%$. Input data are shown in Table 2. Using the dependence (1), the probability of maintaining the discussed power plant in various reliability states, which is associated with different levels of generated power, was determined.

Table 2. Input data

Tabela 2. Dane wejściowe

\begin{tabular}{|l|c|c|c|}
\hline & FOR [\%] & $\boldsymbol{q}$ [-] & $\boldsymbol{p}$ [-] \\
\hline $\begin{array}{l}\text { Average annual number } \\
\text { of start-ups 26/unit }\end{array}$ & 2.44 & 0.0244 & 0.9756 \\
\hline Number of start-ups +50\% & 2.70 & 0.0270 & 0.9730 \\
\hline Number of start-ups +100\% & 2.95 & 0.0295 & 0.9705 \\
\hline Number of start-ups +200\% & 3.47 & 0.0347 & 0.9653 \\
\hline
\end{tabular}

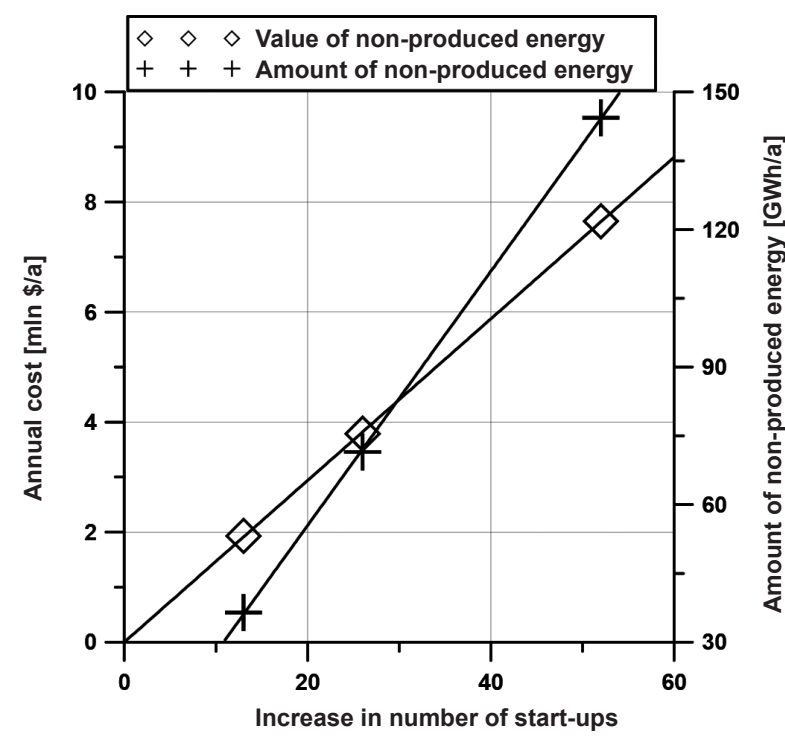

Fig. 8. Amount and market value of non-produced energy due to the increase in the forced outage rate FOR

Rys. 8. Ilość i wartość rynkowa niewyprodukowanej energii z uwagi na wzrost wartości wskaźnika awaryjności FOR
Different variants were analysed, based on which the amount of energy which will not be produced due to the increase of the forced outage rate FOR was determined (Fig. 8). The market value of this non-produced energy is also presented.

\section{EFFECTS OF INCREASED CYCLICALITY OF OPERATION FOR THE ENTIRE SYSTEM}

As already mentioned, the capacity installed in utility power plants in Poland is currently lower than the maximum demand, i.e. the system is not able to meet the needs based only on utility power plants indexed in ARE. In this case, small industrial power plants, heat and power stations or the RES sector become a necessity. A full analysis of the reliability of the power plant system requires determining the cumulative distribution function of the available capacity of the entire system. In order to carry out the analysis, it is necessary to obtain information containing the unit power of individual units that make up the system and their forced outage rates FOR for a given year. The value of the cumulative distribution is numerically calculated with a program using the recursive method [8]. Figure 9 presents the cumulative distribution functions of available power determined for selected years. It can be noticed that the most favourable year for the security of electricity supply was 2013. In the following years, the used units were being decommissioned, which resulted in a decrease in the capacity installed in the system.

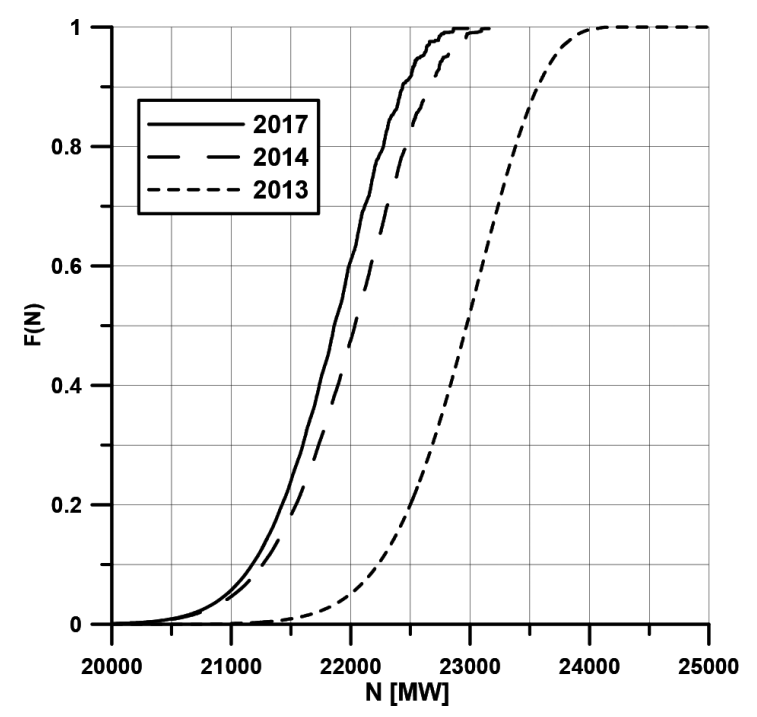

Fig. 9. Available power cumulative distribution function of a system based on coal-fired units

Rys. 9. Dystrybuanta mocy dyspozycyjnej systemu opartego o bloki węglowe

Table 3 illustrates the LOLP (loss of load probability) index values, i.e. the probability of the system's failure to meet the demand of the recipients. The analysis was carried out for the power demand of $22 \mathrm{GW}$. This value was the peak value during the crisis of August 2015 and it was $4 \mathrm{GW}$ lower than the maximum temporary demand during the year. LOLP indicators have high values due to the fact that the analysed power plant 
system bypasses all generating units except for utility power plants indexed in ARE catalogues. The total installed capacity together with industrial and municipal heat and power stations, peak power plants and the group of RES units in Poland is around $43 \mathrm{GW}$ [1]. For such installed capacity, the probability that the system will not cover the demand is several times smaller. However, as the example from August 2015 shows, there are situations in which even $20 \mathrm{GW}$ of excess accumulated power installed in the system may turn out to be insufficient.

The effects of increased cyclicality of operation for the entire system were implemented in model (1). This model assumed that 30 power units with $200 \mathrm{MW}$ power each work as a safeguard for wind power plants. The total power of these units corresponds to the current

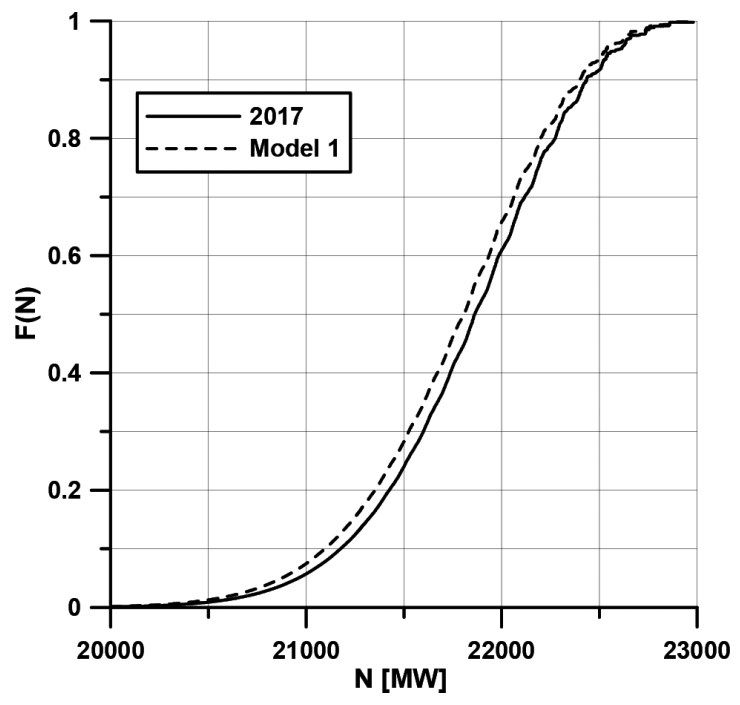

Fig. 10. Available power cumulative distribution function of the system

Rys. 10. Dystrybuanta mocy dyspozycyjnej systemu capacity installed in wind power plants. It was also assumed that due to the specific nature of the operation, the annual number of start-ups of these units will increase by $200 \%$. The cumulative distribution graph for the available power for model (1) is shown in Figure 10 and the LOLP value is given in Table 3.

Table 3. LOLP calculation results

Tabela 3. Wyniki kalkulacji LOLP

\begin{tabular}{|c|c|}
\hline Year & LOLP \\
\hline 2013 & 0.0198 \\
\hline 2014 & 0.4756 \\
\hline 2017 & 0.6083 \\
\hline Model 1 & 0.6567 \\
\hline
\end{tabular}

\section{CONCLUSIONS}

In the era of increasing share of energy coming from RES, the increase in the cyclicality of the operation of units forming the core of the system is a natural consequence [9]. However, coal-fired units were designed for continuous operation. Frequent power fluctuations, shut-downs and start-ups are uneconomical and reduce the durability of the unit. The immediate effect is the increase in the costs of such use, related to expensive start-ups, and the reduction of the unit's production capacity. The long-term effect is the limitation of units' durability due to fatigue and cracking processes. The operation of used units in this capacity is particularly risky. Another consequence is the deterioration of reliability indicators that affect the operation of the entire system. Power plants with a gas turbine have better control properties, therefore it is reasonable to build several such units. The best solution would be to store energy from RES and to consume in peak demand. Despite the work being done, it is not yet possible to store energy on an industrial scale.

\section{REFERENCES}

[1]PSE Polskie Sieci Energetyczne. [Online] Available from: https://www.pse.pl/dane-systemowe/funkcjonowanie-rb/ raporty-roczne-z-funkcjonowania-kse-za-rok/raporty-zarok-2017 [Accessed in April 2018].

[2] Agencja Rynku Energii S.A. Katalog Parametrów Niezawodnościowych Bloków Energetycznych $w$ latach 2000-2017. Warszawa, 2003, 2006, 2009, 2012, 2014, 2015, 2018.

[3] A. Mirandola, A. Stoppato, E. Lo Casto. Evaluation of the effects of the operation strategy of a steam power plant on the residual life of its devices. Energy, 2010, 35, p. 1024-1032.

[4] A. Stoppato, A. Mirandola, G. Meneghetti, E. Lo Casto. On the operation strategy of steam power plants working at variable load: Technical and economic issues. Energy, 2012, 37, p. 228-236.
[5] P. Keatley, A. Shibli, N.J. Hewitt. Estimating power plant start costs in cyclic operation. Applied Energy, 2013, 111, p. 550-557.

[6] N. Kumar, P. Besuner, S. Lefton, D. Agan, D. Hilleman. Power Plant Cycling Costs. NREL Technical Monitor, April 2012.

[7] H. Majchrzak. Wpływ technologii uruchamiania i odstawiania bloków energetycznych elektrowni na straty energii i koszty rozruchowe. Energetyka, 2001, (10), p. 577-579.

[8] R. Billinton, C.L. Wee, G. Hamoud. Digital computer algorithms for the calculation of generating capacity reliability indices. IEEE Transactions on Power Apparatus and Systems, 1982, PAS 101 (1), p. 203-211.

[9]A. Rusin, A. Wojaczek. Trends of changes in the power generation system structure and their impact on the system reliability, Energy, 2015, 92, p. 128-134. 